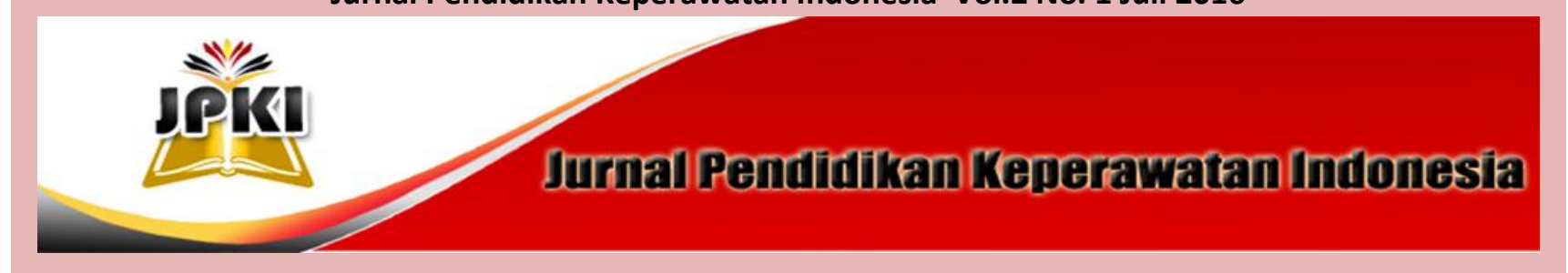

Journal homepage : http://ejournal.upi.edu/index.php/JPKI

\title{
TINGKAT KEMANDIRIAN LANSIA DALAM ACTIVITIES DAILY LIVING DI PANTI SOSIAL TRESNA WERDHA SENJA RAWI
}

\author{
${ }^{1}$ Slamet Rohaedi, ${ }^{2}$ Suci Tuty Putri, ${ }^{3}$ Aniq Dini Karimah \\ ${ }^{123}$ Prodi D3 Keperawatan FPOK Universitas Pendidikan Indonesia \\ Email : 18bfirst@gmail.com
}

\begin{abstract}
ABSTRAK
Meningkatnya usia harapan hidup penduduk dapat menyebabkan peningkatan jumlah lansia dari tahun ketahun. Peningkatan jumlah lansia akan menyebabkan berbagai masalah kesehatan seperti meningkatnya penyakit degeneratif dan kanker yang menyebabkan penurunan produktifitas lansia. Penurunan produktifitas pada lansia terjadi karena penurunan fungsi, sehingga dapat menyebabkan lansia mengalami penurunan kemandirian dalam melaksanakan kegiatan harian. Adapun tujuan dari penelitian ini adalah mengidentifikasi gambaran tingkat kemandirian dalam memenuhi activities daily living. Penelitian ini menggunakan metode deskriptif kuantitatif, dengan teknik pengambilan sampel menggunakan total sampling sebanyak 21 lansia yang berusia 60 - 69 tahun di Panti Sosial Tresna Wredha Senjarawi. Instrumen menggunakan barthel index. Teknik analisa data menggunakan distribusi frekuensi. Hasil penelitian gambaran tingkat kemandirian lansia (60 - 69 tahun) dalam memenuhi activities daily living menunjukan bahwa sebagian besar lansia sebanyak 15 orang (72\%) termasuk dalam ketergantungan sebagian, 3 orang (14\%) termasuk mandiri dan 3 orang (14\%) termasuk dalam ketergantungan total. Bahwa sebagian besar lansia di Panti Sosial Tresna Wredha Senjarawi memiliki ketergantungan sebagian dalam menjalani aktifitas kehidupannya. Diharapkan dapat dikembangkan program - program kesehatan bagi lansia yang dapat meningkatkan kemandirian lansia.
\end{abstract}

Kata Kunci : kemandirian, lansia \& activities daily living

\section{ABSTRACT}

The increase in people's life expectancy may result to the rise in elderly people population from year to year. The rise number in elderly people will lead to various health problems such as the increase of degenerative diseases and cancer that affect the decline in elderly people's productivity. The decrease in elderly people's productivity is caused by the reduction in function so that it will lead to the decrease in elderly people's independence level in following daily activities. The purpose of this research is to identify elderly people's independence level in fulfilling activities of daily living. The current research employed descriptive quantitative, which also applied total sampling as the technique to collect data. The samples were 21 elderly people (aged 60 - 69 years old) in Senjarawi Social Residential. Barthel index was utilized as the research instrument, while frequency distribution was also employed to analyze the research data. The research result on elderly people's independence level (aged 60-69 years old) in fulfilling activities daily living revealed that most of elderly people, 15 persons (72\%), were considered to be partially dependent, 3 persons (14\%) were categorized as independent, while the other 3 persons (14\%) were considered as fully dependent. Based on the findings. That most of elderly people in Senjarawi Social Residential are considered as partially dependent. Suggests that healthcare programs for elderly people should be developed in order to improve elderly people's independence.

Keywords: independence, elderly people \& activities daily living 



\section{PENDAHULUAN}

Salah satu indikator dari suatu keberhasilan pembangunan nasional dilihat dari segi kesehatan adalah semakin meningkatnya usia harapan hidup penduduk. Berdasarkan sumber dari World Population Prospects tahun 2012, bahwa penduduk Indonesia antara tahun 2015 - 2020 memiliki proyeksi rata - rata usia harapan hidup sebesar $71,7 \%$. Meningkat $1 \%$ dari tahun 2010 - 2015. Meningkatnya usia harapan hidup, dapat menyebabkan peningkatan jumlah lanjut usia (lansia) dari tahun ketahun (Kemenkes RI, 2012).

Pengaruh peningkatan populasi usia lanjut ini akan sangat tampak pada hal ekonomi dan sosial, dimana seperti kita ketahui saat ini angka kejadian penyakit kronis, degeneratif, maupun berbagai macam kanker semakin meningkat, juga angka kematian akibat penyakit-penyakit tersebut yang meningkat. Kecacatan akibat penyakit degeneratif pun tidak akan terhindarkan, sehingga menurunkan produktifitas para usia lanjut. Penurunan produktifitas dari kelompok usia lanjut ini terjadi karena terjadi penurunan fungsi, sehingga akan menyebabkan kelompok usia lanjut mengalami penurunan dalam melaksanakan kegiatan harian seperti makan, ke kamar mandi, berpakaian, dan lainnya dalam Activities Daily Living(ADL). Lansia dirasakan semakin mirip dengan anak-anak, dalam ketergantungan pemenuhan kebutuhan dasarnya, hal inilah yang menyebabkan pada akhirnya lansia dikirim ke panti wreda (David, 2013)

Menurut Guntur (2006) mengatakan bahwa proses menua adalah suatu proses menghilangnya secara perlahanlahan kemampuan jaringan untuk memperbaiki diri atau mengganti dan mempertahankan fungsi normalnya, sehingga tidak dapatbertahan terhadap infeksi dan memperbaikinya kerusakan yang diderita. Menurut Orem (2001) menggambarkan lansia sebagai suatu unit yang juga menghendaki kemandirian dalam mempertahankan hidup, kesehatan dan kesejahteraannya. Faktor yang mempengaruhi tingkat kemandirian lansia dalam melakukan aktivitas sehari - hari seperti usia, imobilitas dan mudah jatuh (Ediawati, 2012).

Perubahan fisik yang terjadi pada lansia tentunya akan mempengaruhi kemandirian lansia. Kemandirian adalah kebebasan untuk bertindak, tidak tergantung pada orang lain, tidak terpengaruh pada orang lain dan bebas mengatur diri sendiri atau aktivitas seseorang baik individu maupun kelompok dari berbagai kesehatan atau penyakit (Ediawati, 2012). Kemandirian pada lansia sangat penting untuk merawat dirinya sendiri dalam memenuhi kebutuhan dasar manusia. Meskipun sulit bagi anggota keluarga yang lebih muda untuk menerima orang tua melakukan aktivitas sehari-hari secara lengkap dan lambat. Dengan pemikiran dan caranya sendiri lansia diakui sebagai individu yang mempunyai karakteristik yang unik oleh sebab itu perawat membutuhkan pengetahuan untuk memahami kemampuan lansia untuk berpikir, berpendapat dan mengambil keputusan untuk meningkatkan kesehatanya (Atut, 2013).

Lanjut usia sebagai individu sama halnya dengan klien yang digambarkan oleh Orem (2001) yaitu suatu unit yang juga mengehendaki kemandirian dalam mempertahankan hidup, kesehatan dan kesejateraannya. Kemandirian pada lanjut usia tergantung pada kemampuan status fungsionalnya dalam melakukan aktivitas sehari - hari (Ediawati, 2012).

Dalam kamus psikologi kemandirian berasal dari kata "independen" yang diartikan sebagai suatu kondisi dimana seseorang tidak tergantung pada orang lain dalam menentukan keputusan dan adanya sikap percaya diri (Husain, 2013). Kemandirian merupakan sikap individu yang diperoleh secara komulatif dalam perkembangan dimana individu akan terus belajar untuk bersikap mandiri dalam menghadapi berbagai situasi di lingkungan, sehingga individu mampu berfikir dan bertindak sendiri. Dengan kemandirian seseorang dapat memilih jalan hidupnya untuk berkembang ke yang lebih mantap (Husain, 2013).Kemandirian lansia dalam ADLdidefinisikan sebagai kemandirian seseorang dalam melakukan aktivitas dan fungsi - fungsi kehidupan sehari - hari yang dilakukan oleh manusia secara rutin dan universal (Ediawati, 2013). Untuk menilai ADL digunakan berbagai skala seperti Katz Index,Barthel yang dimodifikasi, dan Functional Activities Questioner (FAQ) (Ediawati, 2013).

Meningkat jumlah penduduk suatu negara maka menyebabkan terjadinya perubahan struktur penduduk negara tersebut. Perubahan struktur penduduk tersebut dapat mempengaruhi angka beban ketergantungan, terutama bagi penduduk lansia. Perubahan ini menyebabkan angka ketergantungan lansia menjadi meningkat. Rasio ketergantungan penduduk tua (old dependency ratio) adalah angka yang menunjukkan tingkat ketergantungan penduduk tua terhadap penduduk usia produktif. Angkatersebut merupakan perbandingan antara jumlah penduduk tua (60 tahun ke atas) dengan jumlah penduduk produktif (15-59 tahun).Angka ini mencerminkan besarnya beban ekonomi yang harus ditanggung penduduk produktif untuk membiayai penduduk tua (Kemenkes RI, 2012).

$\begin{array}{ccc}\text { Hasil } & \text { dari data } & \text { SUSENAS } \\ \text { menunjukkan } & \text { bahwa } & \text { angka rasio } \\ \text { ketergantungan } & \text { penduduk lansia pada } & \text { tahun }\end{array}$


2012 adalah sebesar 11,90 \%. Angka rasio sebesar $11,90 \%$ menunjukkan bahwa setiap 100 orang pendudukusia produktif harus menanggung sekitar 12 orang penduduk lansia. Namun bila dibandingkan per jenis kelamin,angka rasio ketergantungan penduduk lansia perempuan lebih tinggi dibandingkan dengan penduduk lansia laki-laki (12,95\% berbanding 10,86\%)(Kemenkes RI, 2012).

Lansia di Indonesia memiliki angka kesakitan di daerah perkotaan yaitu sebesar $24,77 \%$ yang artinya bahwa setiap 100 orang lansia di perkotaan pada tahun 2012 terdapat 24 lansia yang sakit. Sedangkan dipedesaan $28,62 \%$ yang berarti bahwa setiap 100 lansia di pedesaan pada tahun 2012 terdapat 28 lansia yang sakit. Perlu diperhatikan bahwa lansia yang memiliki penyakit (dalam keadaan sakit) pastinya akan mengalami gangguan dari kemandirian lansia atau lansia tersebut akan memiliki ketergantungan terhadap anggota keluarganya. Dan lansia yang memiliki penyakit pula merupakan salah satu penyebab dari ketidakmandirian lansia(Kemenkes RI, 2012).

Ketergantungan lanjut usia disebabkan kondisi orang lansia banyak mengalami kemunduran fisik maupun psikis. Sedangkan bila dilihat dari tingkat kemndiriannya yang dinilai berdasarkan kemampuan untuk melakukan aktifitas sehari - hari. Kurang imobilitas fisik merupakan masalah yang sering dijumpai pada pasien lanjut usia akibat berbagai masalah fisik, psikologis, dan lingkungan yang di alami oleh lansia. Imobilisasi dapat menyebabkan komplikasi pada hampir semua sistem organ. Kondisi kesehatan mental lanjut usia menunjukkan bahwa pada umumnya lanjut usia tidak mampu melakukan aktifitas sehari - hari (Malida, 2011).

Penduduk lansia berlatar belakang pekerja informal perlu diberdayakan dan dibekali keterampilan oleh kelompok masyarakat atau komunitas yang dibina pemerintah. Hal itu dilakukan agar mereka tetap produktif. Serta mengingatkan agar warga lansia jangan diposisikan sebagai obyek dalam segala hal. Mereka semestinya ditempatkan sebagai subyek dengan melibatkan dan memberi mereka keleluasaan berekspresi. Hal itu akan membuat mereka tetap berdaya dan tidak mengalami depresi (BKKBN, 2014).Peran perawat sangat diperlukan untuk mempertahankan derajat kesehatan para lansia pada taraf setinggi - tingginya sehingga terhindar dari penyakit/ gangguan, sehingga lansia tersebut masih dapat memenuhi kebutuhan dengan mandiri (Malida, 2011).
Dilakukannya pengkajian dengan menggunakan Barthel Index sangatlah penting, terutama ketika terjadi hambatan pada kemampuan lansia dalam melaksanakan fungsi kehidupan sehari - harinya. Kemampuan fungsional ini harus dipertahankan semandiri mungkin. Dari hasil penelitan tentang gangguan status fungsional merupakan indikator penting tentang adanya penyakit pada lansia. Pengkajian status fungsional dinilai penting untuk mengetahui tingkat ketergantungan. Dengan kata lain, besarnya bantuan yang diperlukan dalam aktivitas kehidupan sehari - hari (Ediawati, 2013).

Hasil penelitian mengenai tingkat kemandirian lansia yang dilakukan di Desa Tualango Kecamatan Tilango Kabupaten Gorontalo, menunjukan bahwa dari 31 lansia yang menjadi responden, lansia yang tergolong memiliki ketergantungan berjumlah 22 orang dan yang mandiri berjumlah 9 orang. Jumlah lansia dengan ketergantungan lebih tinggi daripada jumlah lansia yang mandiri, hal tersebut mengindikasikan bahwa kemandirian lansia dalam memenuhi ADL yang berada di Desa Tualango Kecamatan Tilango Kabupaten Gorontalo belum terpenuhi. Terlihat dari observasi kemandirian lansia yang ketergantungan dakam memenuhi ADLnya seperti melakukan aktivitas disaat waktu luang. Rata - rata lansia yang memiliki ketergantungan dikarenakan keterbatasan fisik dan penurunan fungsi tubuh lansia yang tidak bisa lagi beraktifitas sepenuhnya (Husain, 2013).

Penelitian ini sejalan dengan penelitian yang dilakukan oleh Ediawati (2012) menyatakan bahwa di PSTW Budi Mulia 01 Cipayung dan 03 Ciracas sebanyak 143 lansia yang menjadi responden terdapat 140 lansia memiliki tingkat kemandirian yang tinggi dan 3 lansia memiliki tingkat kemandirian yang rendah. Hasil analisa dapat disimpulkan bahwa sebagian responden di PSTW Budi Mulia 01 Cipayung dan 03 Ciracas memiliki tingkat kemandirian yang tinggi. Namun, tingkat kemandirian yang tinggi pada lansia di panti disebabkan karena kondisi panti dengan latar belakang panti sosial dan minimnya jumlah caregiverdi panti tersebut. Terbatasnya bantuan yang diterima lansia dari petugas panti memaksa lansia untuk tetap harus mandiri dalam memenuhi aktivitas kemandiriannya dalam ADL. Banyak ditemukan lansia tetap memaksa untuk memenuhi ADLnya secara mandiri seperti tetap berusaha mandiri untuk pergi ke toilet walaupun sudah tidak mampu berjalan dengan normal. Pada beberapa lansia, mereka tetap berusaha untuk makan secara mandiri walaupun mereka sudah tidak mampu 
untuk memasukkan lebih banyak nasi ke mulut karena penyakit dan kelemahan yang mereka miliki.

Berdasarkan hasil studi pendahuluan, data yang didapat dari tenaga kesehatan yang bertugas di Panti Sosial Tresna Wredha Senjarawi Kota Bandung, kemandirian pada lansia memiliki kecenderungan yang rendah. Hal tersebut diperkuat dengan didapatnya data bahwa dari jumlah keseluruhan lansia yang berjumlah 77 orang terdapat 30 lansia yang ditempatkan di ruang bangsal yaitu ruang dimana para lansia yang membutuhkan bantuan tenaga kesehatan dalam memenuhi kebutuhan sehari - harinya seperti makan, berpindah dari kursi roda ke tempat tidur dan sebaliknya, kebersihan diri, aktivitas toilet, mandi, naik turun tangga, berpakaian, mengontrol defekasi dan mengontrol berkemih. 15 lansia diantaranya memiliki penyakit persendian dan menggunakan kursi roda dan 5 diantaranya memiliki penyakit stroke.

\section{METODE}

Pada penelitian ini mengukur sejauh manatingkat kemandirian lansia dalam memenuhi Activities Daily Living di Panti Sosial Tresna Wredha Senjarawi Kota Bandung.

Responden yang terlibat dalam penelitian ini adalah seluruh lansia yang berusia 60 - 69 di Panti Sosial Tresna Wredha Senjarawi Kota Bandung yang berjumlah 21 lansia.. Waktu penelitian pada tanggal 9 Mei 2016 sampai 13 Mei 2016.

Instrumen penelitian atau alat penelitian yang digunakan dalam penelitian ini adalah Barthel Index. Dalam hal ini peneliti menggunakan barthel index dengan 13 kriteria dengan hasil pengkategorian 3 kategori yaitu mandiri, ketergantungan sebagian dan ketergantungan total. Adapun index ADL barthel yaitu dengan 10 kriteria dan 5 kategori yaitu mandiri, ketergantunga ringan, ketergantungan sedang, ketergantungan berat dan ketergantungan total.

\section{HASIL}

Tabel 1 Distribusi Frekuensi Responden Berdasarkan Jenis Kelamin Pada Lansia Panti Sosial Tresna Wredha Senjarawi

\begin{tabular}{lll}
\hline Jenis Kelamin & Frekuensi & Persentase \\
\hline Laki - laki & 6 & $28,5 \%$ \\
Perempuan & 15 & $71,5 \%$ \\
Jumlah & 21 & $100 \%$ \\
\hline
\end{tabular}

Sumber : Data Primer

Berdasarkan tabel 1 dapat dilihat bahwa jenis kelamin pada lansia di Panti Sosial Tresna Wredha Senjarawi adalah 6 lansia $(28,5 \%)$ laki
- laki dan 15 lansia (71,5 \%) perempuan dengan jumlah 21 lansia (100\%).

\section{Distribusi Responden Berdasarkan Usia Pada Lansia}

Tabel 2 Distribusi Frekuensi Responden Berdasarkan Usia Pada Lansia Panti Sosial Tresna Wredha Senjarawi

\begin{tabular}{cccc}
\hline $\begin{array}{c}\text { Mean } \\
\text { (tahun) }\end{array}$ & $\begin{array}{c}\text { Median } \\
\text { (tahun) }\end{array}$ & $\begin{array}{c}\text { Minimal } \\
(\text { tahun })\end{array}$ & $\begin{array}{c}\text { Maksimal } \\
\text { (tahun) }\end{array}$ \\
\hline 65 & 65 & 60 & 69 \\
\hline
\end{tabular}

Sumber : Data Primer

Berdasarkan data table 2 dapat dilihat bahwa usia rata - rata lansia adalah 65 tahun. Usia pertengahan dari seluruh usia lansia adalah 65 tahun. Usia minimalnya yaitu 60 tahun dan usia maksimalnya yaitu 69 tahun.

\section{Distribusi Frekuensi Responden Berdasatkan Tingkat Kemandirian}

Tabel 3 Distribusi Frekuensi Responden Berdasarkan Tingkat Kemandirian Pada Lansia Panti Sosial Tresna Wredha Senjarawi

\begin{tabular}{lcc}
\hline \multicolumn{1}{c}{ Tingkat Kemandirian } & $\mathbf{f}$ & $\boldsymbol{\%}$ \\
\hline 1. Mandiri & 3 & $14 \%$ \\
2. Ketergantungan & 15 & $72 \%$ \\
Sebagian & & \\
3. Ketergantungan Total & 3 & $14 \%$ \\
Jumlah & 21 & $100 \%$ \\
\hline
\end{tabular}

Sumber : Data Primer

Berdasarkan data tabel 3 dapat dilihat bahwa tingkat kemandirian pada lansia di Panti Sosial Tresna Wredha Senjarawi menunjukan sebagian besar memiliki ketergantungan sebagian yaitu sebesar 15 lansia $(72 \%)$.

\section{PEMBAHASAN}

Lansia adalah proses alami yang tidak dapat dihindari. Semakin bertambahnya usia, fungsi tubuhpun mengalami kemunduran sehingga lansia lebih mudah terganggu kesehatannya, baik keadaan fisik maupun kesehatan jiwa (Maryam dkk,2008). Karena keadaan fisik yangg banyak mengalami kemunduran sehingga membuat lansia memiliki kecenderungan untuk membutuhkan bantuan dalam hal memenuhi kebutuhan sehari - harinya.

Menurut data yang didapatkan lansia yang mandiri ada 3 lansia (14 \%), ketergantungan sebagian ada 15 lansia (72\%) dan ketergantungan total ada 3 orang (14\%). Pada lansia dengan ketergantungan total, 2 lansia di antaranya memiliki penyakit stroke dimana semua kegiatan dalam memenuhi kebutuhan sehari - harinya memerlukan 
bantuan dan 1 lansia di antaranya memiliki penyakit Parkinson dengan keadaan ketergantungan pada obat, jika reaksi pada obat tersebut habis maka lansia tersebut tidak dapat secara mandiri memenuhi kehidupan sehari harinya. Lansia dengan ketergantungan sebagian, rata - rata membutuhkan bantuan dalam hal mencuci pakaian.

Dalam data yang ditemukan pada saat penelitian dilakukan, faktor yang mempengaruhi kemandirian lansia yaitu usia, imobilitas dan mudah jatuh. Faktor pertama yang menentukan tingkat kemandirian lansia yaitu usia. Peneliti membatasi usia responden yaitu 60 - 69 tahun sesuai batasan usia yang ditentukan oleh Depkes.

Faktor kedua yang mempengaruhi kemandirian lansia yaituimobilitas, Imobilitas sendiri merupakan ketidakmampuan lansia untuk bergerak secara aktif. Pada saat penelitian ditemukan bahwa 3 lansia dengan usia 60 - 69 tahun sudah ada yang memiliki penyakit stroke dan Parkinson. Ketiga lansia tersebut masuk ke dalam kategori ketergantungan total karena saat hasil pengkajian ditemukan bahwa semua kriteria yang tercantum dalam barthel index dilakukan dengan cara dibantu. Pada lansia dengan ketergantungan sebagian atau ketergantungan total yang tidak dapat melakukan aktivitas secara mandiri pihak dari panti sosial sudah menyediakan alat bantu seperti kursi roda.

Faktor ketiga yang mempengaruhi kemandirian lansia yaitu mudah jatuh, sesuai dengan pernyataan Ediawati (2013) bila seseorang bertambah tua, kemampuan fisik dan mentalnya perlahan akan menurun. Kemampuan fisik dan mental yang menurun sering menyebabkan jatuh pada lansia, akibatnya akan berdampak pada menurunnya aktivitas dalam kemandirian lansia. Pada saat penelitian ditemukan bahwa di panti sosial tersebut sudah difasilitas dengan pegangan tangan di setiap dinding.

Pada penelitian yang dilakukan oleh Suhartini (2009) bahwa faktor - faktor yang mempengaruhi kemandirian lansia yaitu kondisi kesehatan, kondisi sosial dan kondisi ekonomi. Faktor pertama yaitu kondisi kesehatan yang mempengaruhi tingkat kemandirian lansia di Panti Sosial Tresna Wredha Senjarawi bahwa di panti tersebut sudah cukup memiliki fasilitas kesehatan seperti petugas kesehatan serta alat kesehatan yang menunjang. Namun panti belum memiliki jadwal yang tetap untuk memeriksa kesehatan seluruh lansia secara rutin. Serta kegiatan yang menunjang kemandirian lansia seperti senam lansia sudah lama tidak terlaksana.
Faktor kedua yaitu kondisi sosial, para lansia di panti sudah memiliki jadwal rutinitas untuk mengikuti acara keagamaan atau beribadah bersama. Dengan mengikuti acara keagamaan ataupun diadakannya acara bersama kunjungan dari institusi atau kunjungan donator maka para lansia dapat meningkatkan sosialisasi antar lansia.

Faktor ketiga yaitu kondisi ekonomi, seluruh lansia memiliki kondisi ekonomi yang kurang dikarenakan sudah tidak memiliki sumber keuangan. Sebagian besar lansia tersebut sudah tidak bekerja lagi dan bagi lansia yang masih memiliki keluarga hanya menunggu bantuan dari anak-anak atau saudara. Bagi lansia yang sudah tidak memiliki keluarga hanya menunggu bantuan dari donatur. Penelitian ini didukung oleh teori dari Nugroho (2008) bahwa kondisi lanjut usia akan menyebabkan kemunduran di bidang ekonomi. Masa pensiun akan berakibat turunnya pendapatan, hilangnya fasilitas-fasilitas, kekuasaan, wewenang dan penghasilan.

Pada saat penelitian berlangsung ditemukan bahwa lansia yang mandiri memiliki keadaan dimana seluruh kegiatan dalam memenuhi kehidupan harian dilakukan seluruhnya secara mandiri atau tanpa membutuhkan bantuan. Pada lansia dengan ketergantungan sebagian kegiatan dalam pemenuhan kebutuhan harian yang membutuhkan bantuan antara lain mencuci pakaian dan naik turun tangga. Dan pada lansia dengan ketergantungan total seluruh kegiatan pemenuhan kebutuhan hariannya membutuhkan bantuan.

Tingkat kemandirian lansia dapat menjadi dasar bagi peran perawat dalam menentukan perawatan atau intervensi yang akan dilakukan terhadap lansia. Peran perawat pada lansia yang mandiri dapat memberikan dukungan kepada lansia agar lansia dapat terus mempertahankan kegiatan dalam memenuhi kebutuhannya sehari - hari secara ,mandiri.

Pada lansia dengan ketergantungan sebagian peran perawat dapat membantu memenuhi kebutuhan harian lansia namun hanya pada kegiatan yang membutuhkan bantuan dan pada kegitan yang masih dapat dilaksanakan secara mandiri oleh lansia, peran perawat dapat memberikan dukungan untuk lansia mempertahankan kemandiriannya. Dan pada lansia dengan ketergantungan total peran perawat dapat membantu lansia untuk memenuhi seluruh kebutuhan hariannya sesuai dengan kriteria yang terdapat dalam barthel index. 


\section{SIMPULAN}

Tingkat kemandirian lansia (60 - 69 tahun) dalam memenuhi ADL di Panti Sosial Tresna Wredha Senjarawi diperoleh bahwa sebagian besar lansia sebanyak 15 orang $(72 \%)$ memiliki tingkat kemandirian dengan ketergantungan sebagian.

\section{DAFTAR PUSTAKA}

Arikunto, S. 2010. Prosedur Penelitian Suatu Pendekatan Praktek. Jakarta : Rineka Cipta.

Atut, Andica. 2013. Gambaran Tingkat Kemandirian Landia Di Dusun Blimbing Desa Sukorejo Kecamatan Sukorejo Kabupaten Ponorogo. (KTI, Universitas Muhammadiyah Ponorogo). Diunduh dari : $\quad$ http://digilib.umpo.ac.id /files/disk1/9/jkptumpo-gdl-andicaatut426-1-abstrak,-a.pdf.

Brocklehurst, V. C., Allen,. S. C. 1987. Falls in: geriatric medicine For Students (third ed). London: Churchill Living Stone.

Brunner and Suddarth. Keperawatan Medikal Bedah. Edisi ke - 8. Jakarta : EGC.

David S, Azam. 2013. Pelaksanaan Self-Care Assisstance Di Panti Wredha. Diunduh dari : 985-2079-1-SM.pdf

Depkes RI. 2008, Pedoman Pembinaan Kesehatan Usia Lanjut Bagi Petugas Kesehatan. Jakarta : Depkes.

Ediawati, Eka. 2013. Gambaran Tingkat Kemandirian Dalam Actuvity Of Daily Living (ADL) Dan Resiko Jatuh Pada Lansia DI Panti Sosial Trsna Wredha Budi Mulia 01 dan 03 Jakarta Timur.(Skripsi, Universitas Indonesia). Diunduh dari : digital_20314351S43833-Gambaran tingkat.pdf

Gallo.1998. The driving habits of adults aged 60 years and older. J am Geriatr Soc

Guntur. 2006. Gaya Hidup Lansia Dengan Hipertensi. Diunduh dari : http://digilib.unimus.ac.id/download.php ?id=9823.

Hidayat, A. A. (2011). Metodologi Penelitian Keperawatan dan Teknik Analisa Data. Jakarta : Salemba Medika.

Husain, Salindra. 2013. Hubungan Dukungan Keluarga Dengan Kemandirian Lansia Dalam Pemenuhan Aktivitas Sehari hari Di Desa Tualango Kecamatan Tilango Kabupaten Gorontalo. (Skripsi, Universitas Negeri Gorontalo). Diunduh dari

http://kim.ung.ac.id/index.php/KIMFIK K/article/download/2836/2812

Kane, R. A., \& Kane, R. L. 1981. Assessing the elderly: $a$ practical guide to measurement, Lexington, MA: Lexington Books.

Kemenkes RI. 2012.Situasi dan Analisis Lanjut Usia dan Gambaran Kesehatan Lanjut Usia di Indonesia. Jakarta : Kemenkes.

Lerner, I.M. and Libby, W.J. 1976. Heredity, evolution and society. (2nd ed.) Freeman, San Francisco.

Lueckenotte, A. G. 1990. Pocket guide to gerontologic assessment. Philadelphia: Mosby.

Mahoney Fl, Barthel DW. 1965.Functional evaluation: the Barthel Index. Md State Med J 14:2

Malida, Dyan. 2011. Faktor Yang Mempengaruhi Tingkat Kemandirian Lansia Dalam Melakukan Aktifitas Kehidupan Sehari - hari Di Panti Sosial Tresna Werdha Budi Luhur Kota Jambi.Diunduh dari: http://dyanmalida. blogspot.co.id/2011/05/faktor-yangmempengaruhi-tingkat.html.

Maryam, R. Siti, dkk. 2008.Mengenal Usia Lanjut dan Perawatannya, Jakarta : Salemba Medika.

Notoatmodjo, S. 2013. Metodologi Penelitian Kesehatan. Jakarta : Rineka Cipta.

Nugroho, Wahyudi.2008. Gerontik \& Geriatrik, Jakarta: EGC

Nursal, Dien. 2008. Pengukuran Aktivitas Fisik Pada Lanjut Usia.Padang.

Nursalam. 2008. Konsep dan Penerapan Metodologi Penelitian Ilmu Keperawatan. Edisi 2. Jakarta : Salemba Medika.

Orem, D. E. 2001. Nursing : Concept of practice. (6th Ed.). St. Louis : Mosby Inc.

Potter \& perry. 2005. Fundamentals of nursing: concept, process \& practice .St. Louis: Mosby-Year Book

Stanley dan Beare. 2007. Buku Ajar Keperawatan Gerontik. Edisi 2. Alih bahasa Juniarti dan Kurnianingsih. Jakarta: EGC.

Suhartini. 2009. Pengaruh Faktor-Faktor Kondisi Kesehatan, Kondisi Ekonomi Dan Kondisi Sosial Terhadap Kemandirian Orang Lanjut Usia. Diunduh dari http://www.damandiri.or.id.

Spiegel, Murray. 2007. Statistika. Edisi 3. Jakarta : Erlangga. 